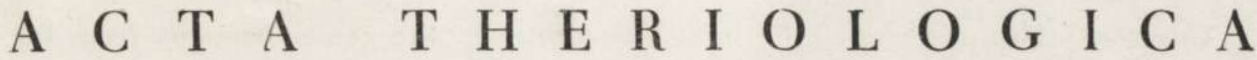

VOL. VIII, 14: 217-226.

BLAŁOWIEŻA

15.X. 1964

Jerzy S I D O R O W I C Z

\section{Comparison of the Morphology of Representatives of the Genus Lemus Link, 1795 irom Alaska and the Palaearctic}

\section{Porównanie moriologii przedstawicieli rodzaju} Lemmus Lin k, 1795 z Alaski i Palearktyki

[With 1 Table]

\section{INTRODUCTION}

This study is a continuation of an earlier one (S i d o r ow i c z, 1960) on problems of the morphology and zoogeography of representatives of the genus Lemmus L in k, 1795 from the Palaearctic. In this study, when analysing a series of skulls of lemmings from the Scandinavian Peninsula and different regions of the northern part of the Soviet Union, hitherto described as separate species, I found that there were no significant differences between these series which could be taken as evidence of taxonomic differences.

Cn these grounds it was established that all the lemmings from the Palaearctic

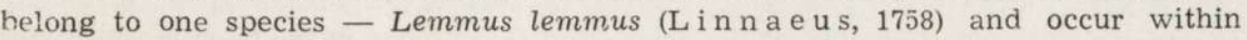
their geographical range in three distinct subspecies:

Lemmus lemmus lemmus ( $\mathrm{L}$ innae us, 1758) - Scandinavia and the Kola F'eninsula.

Lemmus lemmus sibiricus (Kerr, 1792) - Northern part of the Soviet Union from the White Sea to the Bering Straits.

Lemmus lemmus novosibiricus (V in og ra do v, 1924) - New Siberian Islands.

The question of the systematic appurtenance of the brown lemmings from the Ivorth American continent remained an open one.

I gained the impression from the few specimens from Alaska which I saw at that time that they are very similar to the palaearctic forms. 
The systematic position of the brown lemmings of the genus Lemmus from the American continent has hitherto been treated in many different ways. H in ton (1926) gives the following species for this region:

Lemmus nigripes ( $\mathrm{T} \mathrm{r} \mathrm{u}$ e, 1894)

Lemmus alascensis $\mathrm{Mer}$ ria m, 1900

Lemmus yukonensis Me r riam, 1900

Lemmus minusculus Os go od, 1904

Lemmus trimucronatus ( $\mathrm{R}$ i c h a r d s o n, 1825)

Lemmus helvolus ( $\mathrm{R} \mathrm{i} \mathrm{chards} \mathrm{on,} \mathrm{1828).}$

Certain research workers, such as, for instance, M i d d e n d o $\mathrm{fff}$ (1853) described lemmings from Alaska as Myodes obensis B rants, 1827 (given as proper to Siberia).

Elton (1942), Hamilton (1939), Rhode \& Barker (1953) give only the species Lemmus trimucronatus ( $\mathrm{Rich}$ ardson, 1825), for Alaska, as do M a n ning \& M a c pherson (1961).

Ellerman (1949) and $\mathrm{R}$ a u s ch (1953) use the name Lemmus sibiricus trimucronatus (Richardson, 1825). Rausch describes the majority of the "species" given by $\mathrm{Hint}$ on as subspecies.

$\mathrm{Hall}$ \& $\mathrm{Ke} 1 \mathrm{~s}$ on (1959) give two species in their work - Lemmus nigrupes (2 rue, 1894) and L. trimucronatus ( $\mathrm{R} \mathrm{i} \mathrm{chardson,} \mathrm{1825),} \mathrm{splitting} \mathrm{this} \mathrm{later} \mathrm{into}$ 7 subspecies.

As can be seen from the above incomplete review, almost all research workers now agree that the brown lemming forms one species proper to North America. In my present study I shail, like E 11 e r ma n, use the specific name Lemmus sibiricus (K. e r r, 1792).

The Swedish scientist Lindroth (1958) put forward the interesting hypothesis, that all lemmings of the genus Lemmus, with circumpolar occurrence throughout almost the whole of the Arctic regions, constitute one species forming a large number of subspecies. I have endeavoured to check the correctness of this hypothesis, which would seem to be a very probable one, in the present paper.

There is a very large amount of literature on the biology of the brown lemming, and I shall therefore limit myself to mentioning only certain references - E $1 \mathrm{ton}$, 1942; Davis, 1944; We ber, 1950; R a u c h, 1950 and 1953; Th om ps on, 1955; Manning \& M a c pherson, 1961. As shown in this literature, there is considerable similarity between the biology of the brown lemming and that of the palaearctic Lemmus lemmus (C ollet t, 1895).

Owing to the kindness of Dr. William O. Pruitt Jr. and Dr. Robert L. $\mathrm{R}$ a u s ch from Alaska, and Professor Dr. K. Z immerman of Berlin, I obtained the suitable comparative material (skulls), which I needed for work on the present study, and I would like to take this opportunity of expressing my warmest thanks to them.

The present paper is the last one to contain results and conclusions discussed with the late Professor Dr. August De hnel-to whose memory I dedicate this study.

\section{MATERIAL AND METHODS}

This study is based on material consisting of 100 skulls of brown lemmings from Alaska, all coming from one place - Point Barrow. They were lent from the collection of the Arctic Health Research Center at Anchorage, the Zoological Museum of the Humboldt University in Berlin and from the private collection of Dr. William C. Pruiti Jr. of Alaska. 
The material is very uniform, coming from animals caught during a mass appearance, and on this account can be treated as one series (The material from Anchorage and Berlin was collected by Dr. Robert L. R a u s h).

Measurements of the skull (Table 1) were made according to the method which I described in the study of lemmings from the Palaearctic (1960).

In order to obtain the most uniform material possible, I used the skulls of adult lemmings only for comparison. The question of the determination of age in these animals has already been discussed (Sidorowicz, 1960).

Table 1.

Measurements of the skull of different subspecies of lemmings.

\begin{tabular}{|c|c|c|c|c|}
\hline Measurement & $\begin{array}{l}\text { L. lemmus } \\
\text { lemmus }\end{array}$ & $\begin{array}{l}\text { L. lemmus } \\
\text { sibiricus }\end{array}$ & $\begin{array}{c}\text { L. lemmus } \\
\text { novosibiricus }\end{array}$ & $\begin{array}{l}\text { L. lemmus } \\
\text { trimucronatus }\end{array}$ \\
\hline Condylobasal length & $\begin{array}{c}25.2-33.7 \\
(29.18)\end{array}$ & $\begin{array}{c}25.1-35.4 \\
(29.73)\end{array}$ & $\begin{array}{l}27.1-36.7 \\
(32.33)\end{array}$ & $25.3-36.8$ \\
\hline Basal length & $\begin{array}{c}23.6-31.9 \\
(27.60)\end{array}$ & $\begin{array}{c}23.9-33.2 \\
(28.91)\end{array}$ & $\begin{array}{c}26.6-34.8 \\
(30.78)\end{array}$ & $\begin{array}{c}24.1-34.3 \\
(28.15)\end{array}$ \\
\hline Diastema & $\begin{array}{c}7.9-11.6 \\
(9.68)\end{array}$ & $\begin{array}{c}8.0-12.0 \\
(9.86)\end{array}$ & $\begin{array}{c}7.8-12.5 \\
(10.51)\end{array}$ & $\begin{array}{c}8.2-11.8 \\
(9.72)\end{array}$ \\
\hline Occipital breadth & $\begin{array}{c}12.1-16.8 \\
(14.13)\end{array}$ & $\begin{array}{c}13.2-18.6 \\
(15.42)\end{array}$ & $\begin{array}{c}14.8-19.1 \\
(16.65)\end{array}$ & $\begin{array}{c}13.1-17.9 \\
(15.83)\end{array}$ \\
\hline Zygomatic breadth & $\begin{array}{c}15.8-23.2 \\
(19.33)\end{array}$ & $\begin{array}{c}15.7-23.9 \\
(20.31)\end{array}$ & $\begin{array}{c}15.5-24.6 \\
(20.96)\end{array}$ & $\begin{array}{c}15.7-23.8 \\
(21.03)\end{array}$ \\
\hline Interorbital constriction & $\begin{array}{c}3.1-4.3 \\
(3.79)\end{array}$ & $\begin{array}{c}3.3-4.6 \\
(3.93)\end{array}$ & $\begin{array}{c}3.5-4.5 \\
(4.09)\end{array}$ & $\begin{array}{c}3.2-4.3 \\
(3.80)\end{array}$ \\
\hline Height of skull per bullae & $\begin{array}{c}8.6-10.5 \\
(8.91)\end{array}$ & $\begin{array}{c}8.7-11.8 \\
(10.26)\end{array}$ & $\begin{array}{c}10.1-12.3 \\
(10.94)\end{array}$ & $\begin{array}{c}8.9-11.8 \\
(10.75)\end{array}$ \\
\hline Palatal depth & $\begin{array}{c}7.1-10.1 \\
(8.30)\end{array}$ & $\begin{array}{c}6.9-10.8 \\
(8.80)\end{array}$ & $\begin{array}{c}7.8-110 \\
(9.30)\end{array}$ & $\begin{array}{c}7.2-11.1 \\
(9.50)\end{array}$ \\
\hline Depth of brain-case & $\begin{array}{c}7.2-9.6 \\
(8.03)\end{array}$ & $\begin{array}{c}7.2-9.9 \\
(8.50)\end{array}$ & $\begin{array}{c}8.2-10.2 \\
(8.97)\end{array}$ & $\begin{array}{c}7.5-10.2 \\
(8.95)\end{array}$ \\
\hline Maxillary tooth-row & $\begin{array}{c}6.2-8.6 \\
(7.57)\end{array}$ & $\begin{array}{c}6.3-9.3 \\
(7.92)\end{array}$ & $\begin{array}{c}6.5-9.3 \\
(8.39)\end{array}$ & $\begin{array}{c}7.1-9.3 \\
(8.35)\end{array}$ \\
\hline Mandibular tooth-row & $\begin{array}{c}5.8-8.7 \\
(7.36)\end{array}$ & $\begin{array}{c}6.2-8.8 \\
(7.48)\end{array}$ & $\begin{array}{c}6.4-9.2 \\
(8.16)\end{array}$ & $\begin{array}{c}5.8-9.2 \\
(8.04)\end{array}$ \\
\hline No. of animals & 186 & 117 & 22 & 100 \\
\hline
\end{tabular}

It must be emphasised here that in the material consisting of brown lemmings from Alaska there is an interdependence identical to that occurring in the palaearctic lemmings, that is, the reciprocal ratio of palatal height to height of skull measured inter bullae alters with age and may be a convenient age index.

In the brown lemming, as in the palaearctic lemmings, sex dimorphism is not observed in the dimensions of the skull. On this account I have treated the whole material jointly, without division according to sex, in the comparisons made. 
The measurements given in this study refer to migrating specimens, which are slightly smaller than the resident animals ( $\mathrm{T}$ hompson, 1955). I am, however, of the opinion that this is very uniform material, admirably suited to comparative work and drawing conclusions.

The results of measurements are set out in table 1. For the sake of comparison the results of craniometric measurements of three subspecies of the lemming Lemmus lemmus (L.) are given in this table, that is, for Lemmus lemmus ( $\mathrm{L}$ i n $\mathrm{n}$ a e u s, 1758), Lemmus lemmus sibiricus (K e r r, 1792) and Lemmus lemmus novosibiricus (V i nog r a dov, 1924), and measurements of brown lemmings from Alaska.

\section{DISCUSSION OF RESULTS}

Analysis of table 1, comparing the 3 subspecies of palaearctic lemmings and the brown lemmings from Alaska, described as Lemmus sibiricus trimucronatus ( $\mathrm{R}$ i c h a r d s o $\mathrm{n}, 1825),{ }^{1}$ shows very clearly the similarity between these forms, both in the mean values and in the ranges of variation of all the measurements. There are no statistically significant differences between the mean values (condylobasal length, occipital breadth) of the subspecies Lemmus lemmus sibiricus (K e r r, 1792), from the northern part of the Soviet Union and of brown lemmings from Alaska (The Student $t$ test was used here). The above mean values come within the range of error from the mean. In the same way, no morphological differences were found in the structure of the skull between these specimens. This has already been referred to by $\mathrm{H}$ in $\mathrm{t}$ o $\mathrm{n}$ (1926): "Essential cranial, dental and external characters as in L. obensis" (Lemmus obensis $=$ Lemmus lemmus sibiricus).

It is quite clear from the above data that it is possible to compare from all aspects the brown lemming from Alaska, as a taxonomic unit of equal rank, with the subspecies Lemmus lemmus (L.).

In addition to the morphological similarity there is also a biological similarity here - all these subspecies occupy the same ecological niche, play the same part in the tundra biocenosis, have the same enemies, and the same population cycles.

It may therefore be taken that we are concerned here with a phenomenon similar to that in other arctic mammals, such as the bear, polar fox, reindeer, which species have a circumpolar range of occurrence.

In an earlier study (Sidorowicz, 1960) I put forward the assumption that the range of occurrence of the lemming, Lemmus lemmus

$\left.{ }^{1}\right)$ The question of the priority of the specific name sibiricus was sufficiently explained by Elle rman (1949). This study has been omitted in what is otherwise a very comprehensive paper, by $\mathrm{Hall}$ \& $\mathrm{Kels}$ on (1959). 
extends beyond the Bering Straits to include Alaska and Canada, as assumed by Lindroth (1958). Comparison of large series from these areas made it possible to confirm that this assumption is correct.

This applies to morphological observations. It would also presumably be confirmed in studies of the cross-breeding of lemmings from Siberia and Alaska. This type of research is being carried out in the Arctic Health Research Center by Dr. Robert L. R a u s c h, who in correspondence informed me that he had obtained numerous hybrids. The results of his investigations are shortly to be published. This is confirmation obtained by experiment of conclusions reached by means of morphological analysis of the material.

The following subspecies of lemmings of the genus Lemmus ( $\mathrm{H}$ i $\mathrm{n}$ to $\mathrm{n}$, 1926; Ellerman, 1949; Rausch, 1953; Hall \& Kelson, 1959) have been described up to the present from North America:

1. Lemmus sibiricus trimucronatus ( $\mathrm{R} \mathrm{i} \mathrm{chards} \mathrm{on,} \mathrm{1825).}$

"Range. - Eastern Boreal North America, ranging northwards to Port Anderson and the Arctic Coast, eastwards to the Southern and Western shores of Hudson's Bay, and northeast to the neighbourhood of Repulse Bay and in Baffin Land to the Cumberland Peninsula.

Characters. - Essential cranial, dental and external characters as in L. obensis"Hin to 1926 .

2. Lemmus sibiricus helvolus ( $\mathrm{Ri} \mathrm{ch}$ a $\mathrm{rds}$ on, 1828).

"Range. - Northern Part of the Rocky Mountains. Characters. - Essential characters as in other members of the genera" (Hinto $n, 1926)$. Hin ton gives the range as unknown, somewhere in the Rocky Mountains. Described on the basis of one individual (subadult - skull damaged). Hinton assumes that this subspecies may prove to be identical with some other subspecies of the brown lemming.

3. Lemmus sibiricus alascensis $\mathrm{M}$ e r ria m, 1900.

kange of occurrence - Point Barrow, Alaska (whence the whole material used in this stuajy was taken). The skull, according to Hinton (1926), is similar to the skull of Lemmus lemmus, but $\mathrm{M}$ e r $\mathrm{riam}$ does not give its measurements. $\mathrm{H}$ inton assumed that Merriam described this subspecies on the basis of young specimens.

4. Lemmus sibiricus minusculus Osgood, 1904.

"Type locality: Kakhtul River, near its junction with the Malchatna River, Alaska" (H in to n, 1926) (Alaskan peninsula). O s good gives, the condylobasal length as $28.5 \mathrm{~mm}$ for this subspecies, which $\mathrm{H}$ in to $\mathrm{n}$ considers as similar to Lemmus sihiricus alascensis Merriam. This subspecies was described on the basis of one adult male.

5. Lemmus sibiricus yukonensis Merriam, 1900.

Type locality: Alaska. Acc. to $\mathrm{Hall}$ \& $\mathrm{Kels}$ on, 1959, this subspecies occurs throughout Alaska, with the exception of the arctic part (i.e. within the Arctic Circle) and the Alaskan peninsula.

6. Lemmus sibiricus subarcticus Be e \& Hall, 1956.

Brooks Range, Alaska.

7. Lemmus sibiricus harroldi $\mathrm{S} w$ a $\mathrm{t} \mathrm{h}, 1931$

Nunivak Island, Alaska, 
8. Lemmus sibiricus nigripes ( $\mathrm{T} \mathrm{r} \mathrm{u} e, 1894)$.

St. George Island, Pribilof Islands - Alaska.

"Characters. - Essential characters and size nearly as in Lemmus lemmus" (H into $\mathrm{n}, 1926)$. Condylobasal length $-30.0 \mathrm{~mm}$.

As can be seen from the above survey, the subspecies of the brown lemming have been described on the basis of single specimens, sometimes even young specimens. This list is really of an historical character, since it has become the custom in American mammalogical literature to give chiefly the subspecies trimucronatus as a form typical of this continent.

Taking into consideration the absence of important differences between the lemmings from Siberia and Alaska, emphasised even by the authors themselves in describing new "subspecies", and the insufficient grounds for the present splitting of the systematics of subspecies of brown lemmings (as was the case in relation to Siberian lemmings - S i d o r owicz, 1960) I consider that the lemming occurs in principle in one geographical form on the North American continent. Biological and morphological considerations argus in favour of this view.

The debatable form nigripes from St. George Island, Pribilof Islands, remains. This is a smaller form (on the basis of known specimens). These lemmings have a shorter coat, black hind feet and smaller bullae tympanici than in the continental form. Certain research workers consider this form as a separate species Lemmus nigripes ( $\mathrm{T} \mathrm{r}$ u e, 1894) ( $\mathrm{H}$ a 11 \& $\mathrm{K}$ e lis o $\mathrm{n}, 1959)$. On the grounds of the analogy with the systematic position of other lemmings of the genus L e m m u s I am of the opinion that this form cannot be treated as a separate species. Whether it is a subspecies, or variety of the continental subspecies, remains a matter for discussion. It is possible that as a result of geographical isolation and less favourable habitat conditions (small island, poor vegetation), certain genetic factors (a ielatively scanty population isolated for thousands of years), that it certain "dwarf" form has been created. I was not unfortunately able to make comparisons in this study, not having material from this island or suitable craniometric measurements from literature (as far as I am aware, only a small number of specimens are known in American museums). On this account also I consider that until examination has been made of i larger series of lemmings from this island we may assume that this is a separate subspecies.

In the case of the harroldi form described from the Nunivak Island near Alaska, I am of the opinion that we are concerned here at most with a variety (varietas), as in the case of Lemmus lemmus sibiricus ( $\mathrm{K}$ e r r) from the Vaigach and Novaya Zemlya Islands. As it is impossible to speak here of complete geographical isolation (Nunivak Island is connected by 
ice with the American continent during the winter) I consider that there are no grounds for distinguishing this form as a separate taxonomic unit - a subspecies.

Taking as a principle the description of new forms from islands, we should, for instance, consider lemmings from each island of the Canadian Archipelago as separate subspecies, yet lemings from these islands are described (M a nning \& M a c pherson, 1961) as Lemmus sibiricus trimucronatus ( $\mathrm{R} \mathrm{i} \mathrm{chardson,1825).}$

I therefore consider, on the basis of the above arguments, that all lemmings of the genus Lemmus Lin k, 1795, should be considered as one species - Lemmus iemmus (L.), occurring over the whole area in five subspecies. These subspecies constitute geographicaliy isolated varieties.

The subspecies systematics of lemming of the genus Lemmus should now be as follows:

Genus: Lemmus Lin k, 1795.

Species: Lemmus lemmus (L in na e us, 1758). Synonyms: L. sibiricus (Ke r r, 1792); L. obensis Brants, 1825; L. trimucronatus ( $\mathrm{Rich}$ ardson, 1825).

Subspecies: 1. Lemmus iemmus lemmus (Linnae us, 1758). Mountains of Scandinavia and the Kola Peninsula.

2. Lemmus lemmus sibiricus (Ke r r, 1792). From the White Sea to Kamchatka, on the Vaigach and Novaya Zemlya Islands, southern limit of occurrence not exactly known.

3. Lemmus lemmus novosibiricus (V inogradov, 1924). New Sibirian and L.yakhov Islands.

4. Lemmus lemmus trimucronatus ( $\mathrm{R} \mathrm{ichardson,1825).} \mathrm{Alaska,} \mathrm{northern} \mathrm{part}$ of Canada up to the south and west coast of Hudson Bay, part of the Canadian Archipelago, Rocky Mountains.

5. Lemmus lemmus nigripes ( $\mathrm{Tr} \mathrm{u}$ e, 1896). St. George Island, Pribilof Islands, Alaska (Introduced on St. Paul Island).

Consideration of the above materials leads to many interesting conclusions with regard to the formation of new taxonamic units as the result of the phenomenon of geographical isolation.

Lemmings migrated to America from Asia during the Pleistocene period across the bridge formed by the land of Alaska and Siberia, which at that time connected these two continents ( $\mathrm{H}$ a milton, 1939). This was a migration of lemmings in an eastward direction. To the west lemmings reached, in Europe, Ireland, Great Britain, the Pyrenees and Alps (H i n to n, 1926). In Siberia there is a relict form of lemming described as the Amur lemming, Lemmus lemmus amurensis V inoE, r a d o v, 1924, known from a few specimens, the systematic position of which is not fully explained (S id orowicz, 1960). On this account 1 have not given this form in the list of lemming subspecies.

After the glacial period lemmings in Europe, retreating with the 
receding ice-sheet, reached the areas which they occupy at present (mountains of Scandinavia and the Kola Peninsula).

American lemmings are separated by the relatively narrow Bering Straits from the Asian continent and have been so for several thousands of years. This is a natural barrier through which the lemmings cannot penetrate, as in the case of the boundaries between the remaining subspecies of lemmings (White Sea and East Siberian Sea). We therefore have a classic example of geographical isolation which has existed for thousands of years. No new forms have, however, been formed here the lemmings from each side of the Bering Straits do not differ significantly in any respect (morphologically and biologically), cross-breeding freely between themselves.

The explanation of this phenomenon can be sought for only in the unvarying conditions of the geographical habitat - the arctic tundra, which is identical on both sides of the Straits (and further over the whole of the arctic regions).

On the strength of this example it may be assumed that in species-forming processes the fact of alteration in the geographical habitat and next, the question of geographical alteration are of decisive significance (apart, of course, from genetic factors). Lemmings do not form an isolated example of this among mammals, since a similar phenomenon is observed in squirrels (Sciurus vulgaris L.) from the European part of the Soviet Union (Sidorowicz, in preparation), where the boundary between two subspecies is formed by the type of forest stand northern, and of the moderate zone, and not the existance of some definite geographical barrier.

\section{CONCLUSIONS}

On the basis of analysis of brown lemmings from Alaska (100 skulls) and their comparison with specimens from Siberia belonging to the species Lemmus lemmus (L.), the author found that lemmings of the genus Lemmus Link from Alaska, described as Lemmus sibiricus trimucronatus ( $\mathrm{R} \mathrm{ichardson,1825),} \mathrm{form} \mathrm{a} \mathrm{sub-}$ species Lemmus lemmus trimucronatus ( $\mathrm{R}$ i chardson, 1825).

At the same time the author assumes that subspecies described as Lemmus sibiricus helvolus ( $\mathrm{Rich}$ a $\mathrm{ds}$ on, 1828), Lemmus sibiricus alascensis Me rriam, 1900 , Lemmus sibiricus yukonensis M e r riam, 1900, Lemmus sibiricus subarcticus Bee \& $\mathrm{Hall}$, 1956, Lemmus sibiricus minusculus Osgood, 1904 and Lemmus sibiricus harroldi $\mathrm{Sw}$ a $\mathrm{th}, 1931$ are only synonyms of the nominal form.

In this study it has been demonstrated that there are no significant differences between form of the lemming from Alaska and Siberia, despite the geographical isolation which has existed for thousands of years (since the pleistocene period). The author explains this fact by the identical habitat of arctic and subarctic tundra $\mathrm{cn}$ both continents, which is not subject to alteration. 


\section{REFERENCES}

1. Colle t t, R., 1895: Myodes lemmus its habits and migrations in Norway. Kristiania.

2. D a vis, W. B., 1944: Geographical variation in Brown Lemmings (Genus Lemmus). Murrelet, 25: 19-25.

3. Ellermann, J. R., 1949: On the prior name for the Siberian lemming and the genotype of Glis E r x le be n. Ann. \& Mag. Nat. Hist., 12th. ser., 2: 893-894.

4. E 1 t o n, C., 1942: Voles, mice and lemmings. Oxford Univ. Press, New York.

5. H a 11, E. R. \& Kels o n, K. R., 1959: The mammals of North America, 2: 547$1083+79+$ VIII. Ronald Press Co., New York.

6. H a milto n. W. J., Jr., 1939: American mammals. Mc Graw Hill. New York \& London.

7. Hinton, M. A. C., 1926: Monograph of the voles and lemmings (Microtinae) living and extinct. Brit. Mus. London, 1.

8. Lindroth, C. H., 1958: Problemat om glacial overvintring. Svensk Naturvetenskap 1957-58. Stockholm.

9. Manning, T. H. \& M a c pherson, A. H., 1961: A biological investigation of Prince of Wales Island. N. W. T. Trans. of the Royal Can. Inst., 33, 2. Ottawa.

10. M iddendorff, A. T. von, 1853: Sibirische Reise. 2, 2, Wirbelthiere. St. Petersburg.

11. Mille r, G. S., 1896: The genera and subgenera of voles and lemmings. North Amer. Fauna, 12: 1-84.

12. R a u s c h, R., 1950: Observations on the cyclic decline of lemmings (Lemmus) on the Arctic coast of Alaska during the spring of 1949. Arctic, 3, 3: 166-177.

13. $\mathrm{R}$ a u s c h, R., 1953: On the status of some arctic mammals. Arctic, 6, 2: $91-148$.

14. R.hode, C. J. \& B arker, W., 1953: Alaskas Fish and Wildlife. U. S. Dept. of the Interior. Washington.

15. Sidorowicz, J., 1960: Problems of the morphology and zoogeography of representatives of the genus Lemmus Link, 1795 from the Palearctic. Acta theriol., 4, 5: 55-80. Białowieża.

16. S w a r t h, H. S., 1931: The lemming of Nunivak Island, Alaska. Proc. Biol. Soc Wash., 44: 101-105. Washington.

1\%. Thompson, D. Q., 1955: The 1953 lemming emigration at Point Barrow, Alaska. Arctic, 8, 1: 37-45.

18. W e b e r, N., 1950: The role of lemmings at Point Barrow, Alaska. Science, 14, 2890: $552-553$

Yolish Academy of Sciences, Mammals Research Institute, Białowieża, woj. Białystok.
Author's address:

W'arszawa,

Ai. Waszyngtona $38 \mathrm{a} / 8$.

\section{STRESZCZENIE}

$\mathrm{Na}$ podstawie analizy morfologicznej 100 czaszek leminga brunatnego z Alaski oraz porównania ich z lemingami z Syberii, należącymi do podgatunku Lemmus lemmus sibiricus (K e r r, 1792), autor dochodzi do wniosku, iż wobec braku istotnych różnic pomiędzy nimi, należy uznać je za dwa podgatunki gatunku Lemmus lemmus (L.). 
Dla kontynentu Ameryki Północnej właściwym jest podgatunek Lemmus lemmus trimucronatus (R i chards on, 1825).

W pracy tej wykazano duże podobieństwo formy amerykańskiej i syberyjskiej, mimo istniejącej od tysięcy lat izolacji geograficznej (od Plejstocenu). Autor tłumaczy ten fakt nie ulegającym zmianom, identycznym środowiskiem arktycznej tundry, na obu kontynentach. 